\title{
Tegelikkuse mõtestajad: vanasõnad poola grafitis ${ }^{1}$
}

\begin{abstract}
Grzegorz Szpila
Teesid: Käesolev artikkel uurib vanasõnaelemente poola grafitis. Peaeesmärgiks on välja selgitada, kas vanasõnu kasutatakse vaid kontekstivaba sõnamänguna või on seinatarkuste funktsiooniks ka tegelikkuse mõtestamine. Artikkel lähtub eeldusest, et vanasõnadel ja grafitil on nii ühisjooni kui erinevusi, ja et suurem osa paröömilistest seinakritseldustest on olemuselt antivanasõnad. Mitmed uurimused näitavad, et antivanasõnade põhiomaduseks on nende pilkav ja humoorikas olemus.

Artikkel käsitleb näiteid poola grafitikultuurist, seinu ilmestavatest paröömilistest ütlustest, ning üritab nende põhjal välja selgitada, kas kõnealuseid tekste võiks vaadelda kui teatud emotsionaalset meediumi, mis ei eita folkloorseid rahvatarkusi vaid pigem pakub neile alternatiivi, mõtestades igapäevakogemusi ja -tõdesid ning reguleerides inimkäitumist samal viisil kui seda tegid (ja teevad siiani) traditsioonilised vanasõnad.
\end{abstract}

Märksõnad: antivanasõnad, grafiti, pragmaatika, seinakirjutus, vanasõnad

\section{Sissejuhatus}

Paröömiliste ütluste uurimine linnaruumi seintel annab meile pildi vanasõnatarkuste kohalolu ja rolli kohta tänapäeva maailmas. Vanasõnad puudutavad iga inimeksistentsi tahku ning nende funktsioone on juba üsna põhjalikult uuritud. Seevastu pole veel piisavalt tähelepanu pälvinud nende tähendus grafitis, ja näiteks Poolas on tänavakunsti ja konkreetsemalt grafiti uurimisajalugu väga lühike, ning veelgi hilisem on huvi vanasõnagrafiti vastu. Ma näen vajadust mitmetahulise ja põhjaliku käsitluse järele, mis keskenduks esmajoones vanasõnade tuvastamisele linnapildis ja nende funktsioonide sedastamisele. 


\section{Varasemad uurimused poola vanasõnagrafitist}

Poola grafiti akadeemilistes käsitlustes ei mainita just sageli vanasõnade tähendust tänavakunstnike jaoks või rahvatarkuste rolli inspiratsiooniallikana. Ka fikseeritud ütluste kohalolu pole sage teema (vt Guz 2001: 16; Jankowska 1999: 24-25; Michow 1995: 116). Käesoleva artikli autor (vt Szpila 2003) pakkus välja esimese lähenemisnurga teemasse, uurides seinavanasõnade strukturaalseid ja semantilisi aspekte ning pragmaatilist funktsiooni. Edasi liikudes tekstsõnumite paröömikasse (Szpila 2006) pakkusid seinatarkused sobilikku paralleeli, et võrdlevalt uurida nende kahe kontrastse kommunikatsiooniviisi suhtumist vanasõnadesse. Kaks mainitud uurimust (Szpila 2003 ja 2006) keskenduvad mõlemad seega vanasõnade kasutamisviisidele tänapäeval, olgu siis meediumiks linnaruum või mobiiltelefon, ning kirjeldavad vormilisi ja sisulisi muutusi, mida traditsioonilised tekstid on taaskasutuses läbi teinud. Nende artiklite põhjal võib järeldada, et vanasõnad on grafitikunstnike jaoks olulised kultuurimärgid, ning nende haaramine loominguprotsessi on elementaarne, kuigi ükski vaatluse all olnud vanasõnadest ei olnud enam vanasõna selle žanri traditsioonilises tähenduses. See tähelepanek kinnitab Wolfgang Miederi (1993: 58) arvamust, et tänapäeval kasutatakse vanasõnu eelkõige moonutatud kujul (täpsemaks ülevaateks antivanasõnade mõistest vt Voolaid 2012: 247). Siinse autori artikkel aastast 2007 (Szpila 2007), mis keskendub huumorile seinavanasõnades, juurdleb selle väite üle pikemalt ning kirjeldab, kuidas grafiti autorid üritavad moonutuste abil luua seintele humoorikaid ütlusi. Viimatimainitud uurimus toetab parömioloogide väiteid (vt nt Mieder \& Tóthné Litovkina 1999) selle kohta, mis puudutab tänapäevast esmajoones humoorikat suhtumist rahvatarkusse. See kinnitab ka tähelepanekut huumori ja vanasõnade tiheda interaktsiooni kohta nüüdisajal (Skierkowski 2002: 7). Muuhulgas väidetakse (Skierkowski 2002), et tekstsõnumid ongi kaasaja grafiti. Mainida tasub ka käesoleva artikli autori hiljutist uurimust (Szpila 2011), mis pakub põhjalikuma ülevaate poola grafiti vanasõnaelementidest. Sellegipoolest tundub, et teema vajaks veel rohkem lahtikirjutamist, keskendudes just parömioloogilise grafiti pragmaatilisele aspektile. Seniajani pole vanasõnagrafiti paröömilisele taustale suurt tähelepanu pööratud ega uuritud näiteks seda, kuidas vanasõnad linnaruumis toimivad ja mis lisatähendusi nad selles saavad. Linnaruumi tuleks mõista nii füüsilise kui ajalise ruumina - ka käesolev artikkel võtab aluseks Marek Skierkowski käsitluse linnaruumist kui oma kaasaja emotsioonide ja mõttemallide peegeldusest (Skierkowski 2002: 7). 


\section{Materjal}

Kõnealuse uurimistöö materjal pärineb erinevatest internetiallikatest (vt allikate nimekirja artikli lõpus) aga ka raamatutest ja artiklitest ajavahemikus 2002-2011 kogutud seinavanasõnadest. Selle tulemusel saadi sada vanasõnagrafitit, mis jagunevad 63 tüüpi. Pärast 2003. aasta uurimuse (Szpila 2003) ilmumist on lisandunud vaid 8 uut teksti ja 5 tüüpi, mis ilmestab fakti, et 21. sajandi alguses on vanasõnakritselduste (nii traditsiooniliste kui moonutatud vanasõnade) esinemissagedus vähenenud. Praegusse valimisse kaasati 20 teksti, mis on viiendik kogu korpusest.

\section{Grafiti, vanasõnad ja antivanasõnad}

Pole imestada, et grafitit peetakse kunstiliigiks, kus ka vanasõnadel oma oma kindel ja üsna oluline koht ja funktsioon (vt nt Mieder 2007: 20). Samal ajal jääb enamik uurijaid positsioonile, et grafitikunstnike peamiseks eesmärgiks on naeruvääristada traditsioonilisi vanasõnu, piirates nende sõnumit. Paröömilist sisu või (nii vormilist kui loogilis-semiootilist) struktuuri kasutatakse küll vahel selleks, et tutvustada uusi ja tähtsaid tõdesid, kuid sellegipoolest jääb püsima üleolev suhtumine algmaterjali, so vanasõnadesse, mille traditsiooniline tarkusetera põrmustatakse või pööratakse pea peale (vt ka Mieder 2007; Nierenberg 1994). Käesoleva artikli autori varasemad tööd (Szpila 2003; 2009 ; 2011) kinnitavad, et vanasõnagrafiti on traditsioonilise paröömika suhtes agressiivne, rünnates selle kõige olulisemat punkti ehk selle lõplikkust ja paikapanevat tarkust. Grafiti autorite silme läbi ei toimi folkloorne vanasõna enam nn lahkumisrepliigina, millega kõik öeldu saab kokku võetud ja olulisele alla tõmmatud. Stewart (1991: 18) täheldab, et kui "vanasõna on öeldud, siis pole enam midagi lisada". Linnaseintel seatakse selline peaaegu sakraalne käsitlus kahtluse alla, samuti ei jäeta vanasõnu kunagi oma äranägemise järgi modifitseerimata. Selleks kasutatakse tervet plejaadi sisu ja struktuuri muutvaid vahendeid (vt Boronkai \& Litovkina 2007: 108; Litovkina jt 2007: 48). Antivanasõnade võrdlemine nende uute suguvendadega pakub teemasse huvitavaid sissevaateid (Mieder 2007: 19, 42-43). Tuleb märkida, et linnaruumis leiduvad vanasõnaparoodiad on nii põhjalikult töödeldud, et see seab seeläbi küsimärgi alla klassikaliste vanasõnade olemasolu üleüldse, samuti nende lingvistilise märgi rolli traditsioonilise tarkuse asukohana.

Eelmainitut arvestades oleks huvitav sedastada, kas grafiti on peamiselt "huumor, naerulagin, turtsatus, naeratus" (Beck 1982: 74), või hoopis midagi vastupidist, midagi tõsiseltvõetavat. Seda tehes astume rajale, millel võib va- 
ritseda "mõningaid ohte" (Beck 1982). Üks arvamus, mis osaliselt Becki hüpoteesi ümber lükkab, on Frank D’Angelo (1974: 173) väide, et grafiti meenutab mitmes mõttes vanasõnu:

mõlemad on lühidad, otsesed, lakoonilised, tabavad. Nagu ka vanasõnad, sisaldab grafiti viiteid moraalsetele ja eetilistele tõdedele. Nagu vanasõnad, on grafiti tuttavlik ja lähedane oma auditooriumile, sest nad kuuluvad tavakäibesse. Ja nagu vanasõnad, on grafiti autoriteks üksikud inimesed, kuid nende looming jõuab massidesse (D’Angelo 1974).

D'Angelo osutab sellele, et teiste ühisjoonte kõrval edastab ka grafiti tõdesid, mis reguleerivad inimeksistentsi. Kuid sarnasuste kõrval märkab ta ka mõnda erinevust:

Ometi on grafiti vanasõnadest erinev, sest seintel leiduvad tõed on mõningate eranditega pigem konkreetsed kui universaalsed. Vanasõnad on seotud rahvalike tarkustega, samal ajal kui grafiti on peenem ja linlikum. Vanasõnad suhtuvad inimloomusse lahkelt, samal ajal kui grafiti on alati salvav ja satiiriline. Kui vanasõnad osutavad "omade" voorustele, siis grafiti pilab kosmpoliitseid pahesid. Vanasõnad pooldavad lihtsust, naturaalsust ja puhtust; grafiti esindab madalust, rõvedust, jämedust. Vanasõnad kasutavad sõnumi edastamiseks kogunenud tarkust; grafiti kasutab sõnumi edastamiseks naeruvääristamist, pilget, halvakspanu ja põlgust (D’Angelo 1974).

Siinkohal ei taha ma toetada või välistada D'Angelo väiteid, sest see nõuaks põhjalikumat analüüsi kahe kommunikatsioonivormi, vanasõnade ja grafiti, interaktsioonist. Selle asemel pakub mulle huvi viis, kuidas selline kahe žanri sulam - paröömiline grafiti - suhestub ümbritseva reaalsusega, kontekstiga, milles ta on loodud.

Vanasõnu käsitletakse siinses artiklis kui “ametlikku grafitit”. Seda terminit kasutasid esimesena Hermer ja Hunt (1996), kes nimetasid niimoodi igapäevaelu reguleerivaid silte ja märke ametlikus ruumis. Grafiti aga on oma loomuselt otseses mõttes mitteametlik ja vanasõnagrafiti kuulub samuti sellesse kategooriasse. Niisiis on paröömilistel seinatekstidel implitsiitselt reguleeriv funktsioon, milles nad seovad traditsioonilist rahvatarkust uuest kontekstist tulenevate aspektidega. Sellega seoses on huvitav vaadata, kuidas vanasõnagrafiti suhestub oma originaalallika kui lingvistilise märgiga; kuidas ta moonutab algset vormi, et saavutada lõplik tulemus. See on muundamise põhisamm, see on väljakutse, mis puudutab eelkõige vanasõnade kasutamist grafitis, mitte muudes eluvaldkondades. Muundumise puhtalt lingvistilist aspekti siinkohal ei käsitleta, sest seda on juba varasemates uurimustes vaadeldud ja see pole 
praeguse artikli fookuseks. Sellegipoolest ei saa sisulist/lingvistilist ja vormilist analüüsitaset omavahel täiesti isoleerida, sest muutused ühes alas puudutavad ka teist. Alljärgnevalt kirjeldatakse seda, kuidas grafiti suhestub reaalsusega, vaadates mööda muutuste vormilisest poolest ja keskendudes sellele, mida grafitikunstnikud oma vanasõnamoonutustega öelda tahavad.

\section{Grafiti ja hoiakud}

Hoiakud grafitis kooruvad välja pindmiste vormiliste ja sisuliste moonutuste alt juhul kui grafitis aimdub soov sõnastada uusi sissevaateid, mis puudutavad vanade tõdede kehtivust tänapäevamaailmas või uute süstematiseerimata igapäevaeluaspektide sedastamist. Seda tehes järgitakse enamasti kohusetundlikult etteantud paröömilisi šabloone. Fakt, et vanasõnad grafitis üldse esinevad, räägib juba iseenesest selle kasuks, et tänavakunstnikud omistavad neile potentsiaalse regulaatori funktsiooni, mis võiks tuua soovitud muutusi hetkeolukorda. Eriti huvipakkuvad on sellised tekstid, mis ei keskendu üksnes vanade tõdede naeruvääristamisele või ümberlükkamisele, vaid proovivad võrdlemisi tõsiselt sõnastada uut filosoofiat, defineerida suhteid ja pakkuda välja uusi käitumismalle.

Artikli pealkirjas püstitatud küsimus pole lihtsate killast, sest selleks peab välja selgitama, kas seintel leiduvad vanasõnad lahkuvad seintelt ja asuvad elama (urbanistliku grafititarbija) mõttemaailma, või millise väärtuse, populaarsuse ja leviulatuse saavutavad nad potentsiaalse publiku hulgas. Ainult siis saame otsustada, kas seinatarkused seostuvad reaalsusega samal viisil kui traditsioonilised vanasõnad. Meie vanasõnagrafiti käsitlus eeldab, et see nähtus aitab väljendada teatud arvamusi või tundmusi. Kuid ma ei näe selles ainult vaenulikkuse ja frustratsiooni väljapääsu; lisaks sellele vaatlevad seinakirjutused tänapäeva maailma, reageerivad toimuvale, kommenteerivad olude üürikust, korduvust või jäävust jne. Võimalik, et grafitikirjutajad teevad seda kõike lootuses, et nende seinatarkusi võidakse peatselt võtta kui uusi tegelikkuse mõtestajaid.

Kõnealuse vanasõnagrafiti korpuse seast valiti mõned kategooriad, mida võib käsitleda kui hoiakute avaldumise lookuseid. Kategooriate arv on võetud võimalikult väike, kuigi teoreetiliselt on võimalik neis näha ka alamjaotusi. Tuleb ka meeles pidada, et sarnaseid hoiakuid võib esineda mitme kategooria all samaaegselt. Alljärgneva analüüsi tarbeks eraldati korpusest tekste kaheksast kategooriast: kirik, sündmused/uudised, igapäevaelu, moraalsus, filosoofilised mõtisklused, seks, kool ja töö. ${ }^{2}$ Neid kategooriaid käsitletakse järjekorras, mis ei väljenda nende sisulist tähtsust ega kategooria kaalu valimis. 


\section{Kirik}

See rühm sisaldab vanasõnu, mis on sisuliselt seotud religiooni ja (katoliikliku) kiriku institutsiooniga.

[1] Bóg dat, Bóg wziąt, a kto daje i odbiera... (Jumal andis, jumal võttis, tema annab ja võtab...) (http://czarnyhumor.pl/pokaz/graffiti/ - 26. oktoober 2012); ${ }^{3}$

[2] Gdzie diabet nie może tam ja wychędoże. Ksiądz. (Kus kurat ei saa, seal võin mina keppida. Preester.) (http://jonasz.eu/joke11.html - 26. oktoober 2012);

[3] Jaka praca taka taca. (Kuidas töötad, nii ka maksad kümnist) (http://fuuuu.pl/kawa\%C5\%82y/graffiti/2446 - 26. oktoober 2012).

Esimene seinakirjutus ühendab endas kahte vanasõna (Bóg dat, Bóg wziąt; ‘Jumal annab, jumal võtab' ja Kto daje i odbiera, ten się po piekle poniewiera, 'Kes annab ja võtab, lõpetab põrgus'). Kokku kujutab see endast pilkavat kommentaari jumala väidetavalt arukale otsustusoskusele. Teine grafiti võiks olla sama hästi kategoorias, mis koondab seksi puutuvaid vanasõnu, kuid selle esmane tähendus on siiski seotud kirikuga, sest see kommenteerib katoliku preestrite väidetavat kommet olla seksuaalsuhetes kirikuinstitutsioonis töötavate naistega või armukestega väljaspoolt kirikut. Vanasõna originaalversioon viitab naiste võimele õnnestuda lootusetutes ülesannetes: Gdzie diabet nie może, tam babe pośle (Kus kurat ei saa hakkama, sinna saadab ta naise), seepärast kasutatakse seda preestrite moraali kommenteerimiseks (kuigi, ei tohiks välistada vihjeid homoseksuaalsusele). Lõplikus tekstis on vanasõna teine osa asendatud uue struktuurielemendiga, kus verb wychędożę (keppima) riimub teise tegusõnaga może (suutma). Viimane seinakirjutus puudutab Poola katoliku kiriku rahakogumissüsteemi, viidates vanasõnale Jaka praca, taka płaca (Nagu töö, nii ka palk). Siia kategooriasse kuulub kolmas vanasõnaparoodia seetõttu, et sõna płaca (palk) on asendatud sõnaga taca (kandik), ja motivatsiooniks on jällegi kõlaline sarnasus. Sõna taca (ja sellega assotsieeruv) on kahtlemata seotud kümnise kogumise kombega, ja antivanasõna viitab võimalikule ühisosale, mis on inimese palga suurusel ja tema kirikutoetamise harjumustel. See on irooniline, isegi kriitiline kommentaar viisile, kuidas vamulikkond on omastanud hulga varandust, teenides annetustest suurel hulgal raha, kuigi nende töö võib tunduda vähene. Igal juhul väljendab näide 3 mitteisiklikku pahameelt poola vaimulike ja kiriku vastu. 


\section{Sündmused/uudised}

Järgmistel seinakirjutustel on teistsugune sihtmärk: need kommenteerivad Poola ja muu maailma uudiseid. Ühelgi juhul ei saa me öelda, et tegemist on piiratud ajaperioodiga kohe sündmuse järel; kõige vanem sündmustest on näide 6 ja kõige hiljutisem näide 5 .

[4] Komu rano w Sejmie staje, temu Anastazja daje. (See, kellel on hommikul parlamendis erektsioon, seksib Anastazjaga) (http://blog.tenbit.pl/klay92/328 - 26. oktoober 2012);

[5] Zgoda buduje, a Niezgoda to qrwa. (Harmoonia ühendab ja Niezgoda on mõrd) (http://graffiti.humoris.pl/graffiti-napis/7281/zgoda-buduje-aniezgoda-to-qrwa-napis-na-murze-szkoly - 26. oktoober 2012);

[6] Niech żyje Czarnobyl! Co dwie głowy to nie jedna. (Elagu Tšernobõl! Kaks pead on parem kui üks) (http://www.ciapek.pl/t/33/graffiti/ - 26. oktoober 2012).

Seinakritseldus, kus mainitakse Anastazjat, sisaldab kultuurispetsiifilist vihjet naisele, kes usutavasti oli seksuaalvahekorras paljude Poola parlamendiliikmetega 1990. aastatel. Vanasõnaparoodia ise viitab originaalile Kto rano wstaje, temu Pan Bóg daje (Kes tõuseb vara, sellele jumal annab; Varajane lind leiab ikka tera, vt ka näide 16). See on samaaegselt kommentaar poliitilisele elule (eriti Poola parlamendi, Seimi, liikmete omale), aga ka seksile, kuigi esimene tähendus on tugevam. 5. näide on üks hilisematest lisandustest selles korpuses, ja sisaldab viidet avaliku elu tegelastele Katarzyna Niezgodale, kes on kihlatud Tomasz Kammeli, tuntud televisiooninäoga. See on solvav märkus kõnealuse naise pihta (qrwa on moonutus poolakeelsest sõnast kurwa, 'lits'), ja tekstist ei selgu ühtegi tegelikku fakti või kommentaari, mis seda naist iseloomustaks. Seinakirjutuse teeb huvitavaks sõnamäng, milles vastandatakse sõna zgoda (harmoonia) sarnase kõlaga sõnaga niezgoda (disharmoonia, segadus). Me ei saa välistada, et autori ajendiks oli väljendada isiklikku vastumeelsust naise suhtes, kes on olnud kollase pressi huviorbiidis kui Kammeli väljavalitu ja kelle suhe mehega on tekitanud pisut avalikku uudishimu (kui tagasihoidlikult väljenduda). Selle rühma viimane näide (6) pilkab süngelt Tšernobõli katastroofi ja tuumakiirguse mõju. Vanasõna Co dwie gtowy, to nie jedna (Kaks pead on parem kui üks) kasutatakse siin originaalvormis, ja irooniline lisand (Elagu Tšernobõl!) muudab vanasõna päevakajaliseks kommentaariks. 


\section{Igapäevaelu}

Siia kategooriasse on koondatud sellised seinatekstid, mis viitavad igapäevaelu põhiaspektidele, nimelt elukeskkonnale (7) ja tervisele (8 ja 9 ).

[7] Im dalej w las tym więcej butelek (Mida sügavamal metsas, seda rohkem pudeleid) (http://www.ciapek.pl/t/33/graffiti/ - 29. oktoober 2012);

[8] Czas goi rany, ale nigdy nie zaszkodzi zasięgnąć opinii lekarza (Aeg parandab kõik haavad, aga soovitatav on küsida ka arsti arvamust) (http://humorek3.w.interia.pl/grafiti.html - 29. oktoober 2012);

[9] Gdzie dwóch się bije, tam korzysta dentysta (Kui kaks inimest kaklevad, siis hambaarst saab sellest kasu)

(http://graffiti.humoris.pl/graffiti-napis/7206/gdzie-dwoch-sie-bije-tamkorzysta-dentysta -29. oktoober 2012).

Need kolm näidet muudavad originaalvanasõnade tähenduse sõna-sõnaliseks, piirates nende kasutusala vaid kindlate situatsioonidega. Esimeses neist (7: Im dalej $w$ las, tym więcej drzew; 'Mida sügavamal metsas, seda rohkem puid') on vahetatud välja üks sõna, drzewo (tekstis mitmuse genitiiv sõnast drzew, 'puu'), mille asemel on sõna butelka (mitmuse genitiiv sõnast butelek, 'pudel'). See vanasõnaparoodia juhib tähelepanu Poola (ja ülejäänud maailma) metsade reostatusele. Teine näide (8) laiendab algset vanasõna Czas goi rany (Aeg parandab kõik haavad), lisades sellele fraasi, mis muudab vanasõna tähenduse sõna-sõnaliseks. Vanasõna esmane sisu, st valu ja kannatused mööduvad aja jooksul ise, vahetatakse välja, ja "haavad" mõistetakse ainult selle sõna füüsilises tähenduses, mistõttu soovitatakse konsulteerida spetsialisti - arstiga. Seda saab nüüdsel kujul tõlgendada ka nii, et füüsiliste probleemide puhul tuleb pöörduda arsti juurde ja ei tohi probleemi eirata. Selle sektsiooni viimases, 9. näites on toimunud järjekordne vahetus. Sõna trzeci (kolmas) on lauses Gdzie dwóch się bije, tam trzeci korzysta (Kus kaks kaklevad, seal kolmas saab kasu) asendatud sõnaga dentysta (hambaarst). Selle vahetuse tulemusel võib "kaklust" mõista mitte ülekantud tähenduses, vaid reaalse kaklusena, mille tulemusel võidakse osalejatel hambad välja lüüa. Tähenduse muutudes võib tõesti tunduda asjakohane soovitus minna hambaarsti juurde. See paröömiline grafiti on labane tähelepanek füüsilise vägivalla tagajärgedest. 


\section{Moraalsus}

Kogu korpuses on ainult üks näide, mis viitab moraalsusele, ja seda oma päritolu tõttu piiblist.

[10] Nie rób drugiemu, co tobie niemite - powiedziat masochista (Tee teistele seda, mida sa tahad, et sulle endale tehakse - ütleb masohhist) (http://www.ciapek.pl/t/33/graffiti/ - 29. oktoober 2012)

Vanasõna Nie czyń drugiemu, co tobie niemite (Ära tee teistele seda, mida sa ei taha, et sulle tehakse) on siin tõlgendatud masohhisti (grafiti autori?) silme läbi. Vanasõna moonutades lõi autor velleristliku struktuuri. Kuigi vanasõna algne laiem mõte on kitsendatud masohhistlike kommete kohta käivaks, on selle moraal säilinud kui teemakohase käitumiskoodeksi täisväärtuslik osa, vajalik nõuanne vastavates seksuaalpraktikates, või siis üldise seksuaalkäitumise reegel.

\section{Filosoofilised mõtisklused}

Siia kategooriasse kuuluvad seinakirjutused, mis esindavad nö eksistentsiaalse grafiti suunda (Michow 1995: 112). See hõlmab grafitit, mis kirjeldab inimelu ja -kogemust, ja mille aluseks on vanasõnad, mis keskenduvad samuti elufilosoofiale kõige üldisemas mõttes (vt Skierkowski 2002: 7). Valitud näited kirjeldavad tarkust (11), sõprust (12), ebaõnne (13) ja armastust (14):

[11] Mądry gtupiemu ustępuje ... i dlatego ten świat tak wygląda (Targem annab järele ... ja sellepärast on maailm selline nagu see on)

(http://graffiti.humoris.pl/graffiti-napis/7377/madry-glupiemu-ustepujei-dlatego-ten-swiat-tak-wyglada - 29. oktoober 2012);

[12] Pewnego przyjaciela poznasz w sytuacji niepewnej (Sa kohtad tõelist sõpra ebakindlates oludes)

(http://michal671.ubuntu-pomoc.org/forum/showthread.php?tid=321 29. oktoober 2012);

[13] Nie ma tego dobrego, co by na złe nie wyszło (Ei ole heategu, mis ei muutuks halvaks) (http://www.ciapek.pl/t/33/graffiti/ - 29. oktoober 2012);

[14] Stara miłośc nie rdzewieje, ale niestety - siwieje (Vana arm ei roosteta, vaid läheb kahjuks halliks) (http://windows7forum.pl/501-x-graffiti20722-t - 29. oktoober 2012). 
Esimene on täiuslik antivanasõna-žanri esindaja. Laiendusse lisatud kommentaar osutab sellele, mis juhtub, kui vanasõna Mądry gtupiemu ustępuje (Targem annab järele) liiga sõna-sõnaliselt järgitakse. Teine näide (12) on parafraas originaalist Prawdziwych przyjaciót poznaje się w biedzie (Tõelist sõpra tunned hädas). Parafraas annab edasi sama mõtte, mis algne versioon, kuid muutus puudutab sõna pewny (tõeline, usaldusväärne), mis on asendatud sõnaga niepewny (ebakindel, ebaturvaline). Tulemust võib võtta kui vana rahvatarkuse kinnitust. 13. näite originaalstruktuur on tagurpidi pööratud, nii et lõpptulemus (õnn; Nie ma tego złego, co by na dobre nie wyszło (pole halba, mis ei muutuks heaks)) on toodud hoopis algpunktiks. Suhted on tagurpidi pööratud, ja kuigi see ei eita vanasõna esialgset sõnumit, konstrueeritakse uus tarkusetera, mis on tunduvalt vähem optimistlik kui originaal. Viimases näites (14) korratakse vana tõde Stara mitość nie rdzewieje (Vana arm ei roosteta), kuid selle sõnasõnalist mõistmist toetab lisatud fraas, mis tõdeb, et mida vanemaks me saame, seda hallimaks muutume, olgu siis armastusega või ilma.

\section{Seks}

Siia kategooriasse kuuluvad vanasõnaparoodiad, mis viitavad seksile.

[15] Palcówka jest srebrem, a mineta złotem (Näpukas on hõbe, suuseks on kuld) (http://jonasz.eu/joke11.html - 13. mai 2012);

[16] Dlaczego pedały wstaja wcześnie? Kto rano wstaje, temu pan Bóg daje (Miks ärkavad peded vara? Sest varane lind leiab ussikese) (http:// jerzy.friko.pl/inne.html - 29. oktoober 2012).

Näide 15 on hinnang kahele seksuaaltegevusele, käega rahuldamisele ja suuseksile, millest viimast kiidetakse paremaks. Vihjatakse tuntud vanasõnale Mowa jest srebrem, a milczenie złotem (Rääkimine hõbe, vaikimine kuld). Teine tekst võib tunduda jumalavallatu neile, kes võtavad seda sõna-sõnalt: et jumal premeerib vara tõusvaid homoseksuaale seksiga. Teistsugune tõlgendus lubab käsitleda aga jumala figuuri metafoorselt. Võtmesõnaks on sõna daje (dawać tähendab 'andma'), mida kasutatakse poola keeles meeste kohta, kes homoseksuaalses vahekorras on passiivses rollis. Samas võib seda mõista ka neutraalselt nagu originaali Kto rano wstaje, temu Pan Bóg daje puhul (Kes vara tõuseb, sellele jumal annab; Varane lind leiab tera), mil seda võib tõlkida sõnade tasustama, aitama, toetama abil. 


\section{Kool}

Selles rühmas on vaid üks näide, mis viitab eksimatult Poola koolielule.

[17] Pokorny uczeń z dwóch ściąg korzysta (Alandlik tudeng kasutab kahte spikrit) (http://www.jajcarz.ksiazkowo.net/kawal/2323/ - 29. oktoober 2012).

See seinakirjutus kannab väga praktilist reguleerivat funktsiooni Poola ühiskonnas. Testides ja eksamitel spikerdamine on Poolas väga levinud igal koolitasemel ja kuigi ametlikult leiab see halvakspanu, on käesoleva antivanasõna eesmärgiks anda juhendeid, kuidas õpetaja petmises paremaks saada. Originaal Pokorne ciele dwie matki śsie (Alandlik vasikas joob kahe ema piima) on säilinud, kuid selle üldine sisu on muudetud konkreetseks, ning sellisel kujul käib tekst koolikäitumise ja selle reguleerimise kohta. Paradoksaalselt soovitab see eetiliselt kaheldavat käitumist juba algses versioonis, mis pole tegelikult vanasõnade puhul kuigi tavaline.

\section{Töö}

Viimane kategooria sisaldab tekste, mis peatuvad töö olemusel, väärtusel, ja selle mõjul inimesle.

[18] Jak cię widzą to pracuj (Tööta, kui sind vaadatakse) (http://www. hwbaran.eu/Graffiti.htm - 29. oktoober 2012);

[19] Uczciwościa i praca ludzie się męcza (Ausus ja töö teeb inimesed väsinuks) (http://graffiti.humoris.pl/graffiti-napis/9172/uczciwoscia-ipraca-ludzie-sie-mecza - 29. oktoober 2012);

[20] Żadna praca nie hańbi, ale każda męczy (Ükski töö pole häbiasi, kuid iga töö väsitab su ära) (http://pszoniak.net/edukacja/strony/graffiti. htm - 29. oktoober 2012).

Suhte töötegemisse võib kokku võtta nende kolme seinakirjutuse põhjal järgmiselt: töö on väsitav tegevus ja kui sa just pead tööd tegema, siis tee seda ainult selleks, et teised näeksid, et sa töötad. Esimene tekst viitab vanasõnale Jak cie widza, tak cie malują (Nagu sa paistad, nii sind värvitakse) millel pole midagi tegemist tööga. Originaali sisu on muudetud nii, et see kehtiks ka töötegemise kohta. Tulemus väljendab tähelepanekut, et tööd peaks tegema ainult siis, kui 
keegi jälgib ja kontrollib. Näidete 19 ja 20 aluseks on vanasõnad Uczciwościq $i$ praca ludzie się bogaca (Ausus ja raske töö teevad rikkaks) ja Żadna praca nie hańbi (Ükski töö pole häbiasi). Suhtumine töösse, mis väljendus originaalides, on muudetud nii, et see väljendaks üldist negatiivset suhtumist töösse (ja ka aususse).

\section{Kokkuvõte}

Näited, mida selles artiklis analüüsiti, viitavad sellele, et vanasõnagrafiti sisaldab erinevaid tundmusi ja arvamusi, mis on olemuselt üldtuntud tõed ja kannavad nähtavaid ühisjooni traditsiooniliste vanasõnadega. Neis peegeldub ka tekstide autorite, grafitikunstnike, tähelepanelikkus ja nende üldisemad hinnangud ühiskonnale, mis on universaalsed isegi juhul, kui konkreetne sihtmärk on olemas. Vaataja võib leida vanasõnaparoodiatest mitmeid globaalseid vihjeid. Seinatarkused kasutavad osavalt ära originaalparöömika kategoorilist kõneviisi ja mõjujõudu ning kannavad selle üle uutele teemadele, mida vanasõnad traditsiooniliselt ei käsitlenud. On sellegipoolest ilmne, et tänavakunstnikud valivad vanasõnažanri just siis, kui nad soovivad väljendada oma arvamust - seda ei saa öelda kõikide teiste grafitiliikide kohta, mille semantika ulatub loendamatult rohkematesse kategooriatesse (vt Sawicka 1993; Michow 1995; Skubalanka 1999).

Kõige eelöeldu valguses jõuame tagasi algse küsimuse juurde, kas vanasõnagrafiti võib olla tegelikkuse mõtestaja ja reguleerija. See küsimus ei olegi nii lihtne. Kui me võtame arvesse fakti, et seinakritseldused, mis kasutavad algallikana vanasõnu, on olemuselt antivanasõnad, siis peaksid need funktsioneerima antiregulaatoritena. Nad töötavad üleüldse regulaatorite kui selliste vastu. Kuid kui me vaatleme seda materjali kui antivanasõnu, mis viitavad konkreetsetele tarkuseteradele, siis pole need antiregulaatorid, vaid on pigem vahendiks, mille abil revideerida ja ümber hinnata süsteemi, mille on loonud traditsioonilised vanasõnad. Isegi need seinatarkused, mis moonutavad vanasõnu ilma konkreetse eesmärgita ja võtavad seda lihtsalt kui loovat sõnamängu, tunduvad osutavat sellele, et traditsiooniliste rahvatarkuste kõigutamatut mõjuvõimu tuleks käsitleda kriitiliselt. Artiklis vaadeldud näited, mis moodustavad vaid osakese tervest vanasõnagrafiti arhiivist, annavad tunnistust sellest, et vanasõnade algse mõtte modifitseerimisel on üsna otsene põhjus. Tulemus ei ole mitte niivõrd antivanasõna, ega isegi mitte anti-vanasõna-kui-institutsioon. Selle asemel peegeldavad nad püüdu tulla toime lingvistikaülese reaalsusega, nagu seda tegid ka traditsioonilised vanasõnad. Kuigi vaevumärgatavalt, 
kõnetab vanasõnagrafiti ka muutuvat maailma, muutuvat väärtussüsteemi ja muutuvaid eelistusi. See pole üllatav, sest vanasõnad ja nende tuletised ongi väga tundlikud reaalsuse muutuste suhtes (Komenda-Earle 2009). Selles mõttes võiks seinatarkusi võtta kui uusi regulaatoreid, neoregulaatoreid, mis asendavad tänapäevamaailmas kõlapinnata jäänud vanasõnu sellistega, mis süstematiseerivad praeguse ajastu inimelu ja -kogemust. Isegi kui need seinakirjutused ei saavuta püsivat staatust tegelikkuse mõtestajana, näitavad nad, et reaalsus, mida reguleerisid traditsioonilised vanasõnad, on muutumas, ja inimestel on vaja uusi vahendeid, ehk isegi mitte vanasõnade uues vormis (anti-, pseudo- vm vanasõnadena), vaid hoopis mingil muul kujul. Vanasõnagrafiti püsimajäämine arvamuste peeglina sõltub paljudest faktoritest nagu väljendatud arvamuste ajakohasus, uute vormide aktsepteerimine ja levik, ning selliste märkide vajalikkus ühiskonnas tervikuna.

\section{Tõlkinud Liisi Laineste}

\section{Kommentaarid}

1 Käesoleva artikli tõlkimist toetas ETF grant 8149.

2 Michow (1995) pakub välja poola grafiti üldise klassifikatsiooni. Siinses uurimuses toodud kategooriad kattuvad nendega, kuigi Michow klassifikatsioon katab kogu grafiti ja sisaldab seega rohkem erinevaid tüüpe. Vt ka Sawicka (1993) ja Skubalanka (1999).

3 Autor on lisanud poolakeelsetele vanasõnagrafitidele sõnasõnalise tõlke (inglise keelest tõlkinud toimetaja L. L.), mõnel juhul ka poolakeelse originaalvanasõna ja selle rahvusvahelise vaste (selle puudumise korral ainult tõlke). Alles on jäetud algupärane kirjapilt.

\section{Internetiallikad}

http://pszoniak.net/edukacja/strony/graffiti.htm

http://www.jajcarz.ksiazkowo.net/kawal/2323/

http://www.ciapek.pl/t/33/graffiti/

http://michal671.ubuntu-pomoc.org/forum/showthread.php?tid=321

http://windows7forum.pl/501-x-graffiti-20722-t

http://graffiti.humoris.pl

http://jerzy.friko.pl/inne.html

http://czarnyhumor.pl/pokaz/graffiti/ 
Grzegorz Szpila

http://jonasz.eu/joke11.html

http://fuuuu.pl/kawa\%C5\%82y/graffiti/2446

http://blog.tenbit.pl/klay92/328

http://humorek3.w.interia.pl/grafiti.htm

\section{Kirjandus}

Beck, James P. 1982. Graffiti: The Vulgar Blackboard's Wit. The English Journal 71 (3), lk 73-74 (doi:10.2307/817036).

Boronkai, Dóra \& Litovkina, T. Anna 2007. Appreciation of Humor in Hungarian Anti-Proverbs. Acta Ethnographica Hungarica 52 (1), lk 105-134 (doi:10.1556/ AEthn.52.2007.1.4).

D’Angelo, Frank J. 1974. Sacred Cows Make Great Hamburgers: The Rhetoric of Graffiti. College Composition and Communication 25 (2), lk 173-180.

Guz, Bartłomiej 2001. Język wchodzi w grę - o grach językowych na przykładzie sloganów reklamowych, nagłówków prasowych i tekstów graffiti [Mängu tuleb keel - Keelemängud hüüdlausetes, pealkirjades ja grafitis]. Poradnik Językowy 10, lk 9-20.

Hermer, Joe \& Hunt, Alan 1996. Official Graffiti of the Everyday. Law \& Society Review 30 (3), lk 455-480 (doi:10.2307/3054125).

Jankowska, Katarzyna 1999. Próba klasyfikacji napisów graffiti [Grafiti esialgne klassifikatsioon]. Literatura Ludowa 3, lk 24-25.

Komenda-Earle, Barbara 2009. Sprichwörter und Antisprichwörter: Kultur und (Anti) Kultur [Vanasõnad ja antivanasõnad: kultuur ja (anti)kultuur]. Zeszyty Naukowe Uniwersytetu Szczecinskiego. Colloquia Germanica Stetinensia16, lk 169-179.

Litovkina Tóthné, Anna \& Vargha, Katalin \& Barta, Péter \& Hrisztova-Gotthardt, Hrisztalina 2007. Most Frequent Types of Alteration in Anglo-American, German, French, Russian and Hungarian Anti-Proverbs. Acta Ethnographica Hungarica 52 (1), lk 47-103 (doi:10.15556/AEthn.52.2007.1.3).

Mieder, Wolfgang 1993. Proverbs are never out of Season. New York: Oxford University Press.

Mieder, Wolfgang 2007. Anti-Proverbs and Mass Communication: The Interplay of Tradition and Innovative Folklore. Acta Ethnographica Hungarica, Vol. 52, No. 1, 1k. 17-45 (doi:10.1556/Aethn.52.2007.1.2).

Mieder, Wolfgang \& Litovkina T., Anna 1999. Twisted Wisdom: Modern Anti-Proverbs. Burlington: The University of Vermont.

Michow, Elżbieta 1995. Polskie graffiti [Poola grafiti]. Polonica XVII, lk 109-120. 
Nierenberg, Jess 1994. Proverbs in Graffiti. Taunting Traditional Wisdom. Mieder, Wolfgang (toim). Wise Words. Essays on the Proverb. New York \& London: Garland Publishing, Inc, lk 41-58.

Sawicka, Grażyna 1993. Językowy obraz rzeczywistości społecznej i politycznej w graffiti. [Sotsiaalse ja poliitilise reaalsuse lingvistiline kajastus grafitis]. Anusiewicz, Janusz \& Siciński, Bogdan (toim). Język a kultura 11: Język polityki a wspótczesna kultura polityczna [Keel ja kultuur 11: Poliitika ja tänapäeva poliitkultuuri keel]. Wrocław: Towarzystwo Przyjaciół Polonistyki Wrocławskiej, lk 163-175.

Skierkowski, Marek 2002. Graffiti [Grafiti]. Wrocław: Wydawnictwo Fox.

Skubalanka, Teresa 1999. Język graffiti [Grafiti keel]. Stylistyka VIII, lk 89-103.

Stewart, Susan 1991. Notes on Distressed Genres. Journal of American Folklore $A F$ 104, lk 5-31 (doi:10.2307/541131).

Szpila, Grzegorz 2003. Co mur, to mądrość narodu - przysłowie w graffiti po polsku [Igal seinal on oma rahvatarkus - Vanasõnad poola grafitis]. Literatura Ludowa 3, lk 35-42.

Szpila, Grzegorz 2006. Przysłowiowe SMS-y - paremia w komunikacji elektronicznej [Vanasõnad sms-ides - Paröömika elektroonilises kommunikatsioonis]. Literatura Ludowa 1, lk 33-40.

Szpila, Grzegorz 2007. Humour as a Tool in Communicating Proverbial Wisdom in Polish Graffiti. Acta Ethnographica Hungarica 54 (1), lk 105-114 (doi:10.1556/ AEthn.54.2009.1.9).

Szpila, Grzegorz 2011. Mural Wisdom. Witalisz, Alicja (toim). Across Borders IV. Krosno: PWSZ Krosno, lk 321-333.

Voolaid, Piret 2012. In Graffiti Veritas: A Paremic Glance at Grafiti in Tartu. Laineste, Liisi \& Brzozowska, Dorota \& Chłopicki, Władysław (toim). Estonia and Poland. Creativity and Tradition in Cultural Communication. Tartu: ELM Scholarly Press, lk 237-268.

\section{Summary}

\section{Regulating the reality? Proverbs in Polish graffiti}

Grzegorz Szpila

Keywords: anti-proverbs, graffiti, pragmatics, mural inscription, proverbs

The paper investigates proverbial elements in Polish mural inscriptions. The main aim of the paper is to consider paremic mural inscriptions with an eye to determining if proverbs are used in Polish graffiti only as content-free play on traditional folk wisdom. The starting point in this analysis is the assumption that proverbs and nonparemic graffiti exhibit both similarities and differences and that most paremic uses in 
graffiti can be classified as anti-proverbial in character. Many studies suggest that the dominant feature of anti-proverbs is their mocking and humorous nature. The paper then tries to establish if mural anti-proverbs can be treated also as carriers of various sentiments which do not necessarily deny the traditional nuggets of wisdom, but are used to convey observations and truths based on them, which pertain to contemporary reality and regulate it in the same way as traditional paremias do. 